\title{
Methicillin-resistant Staphylococcus aureus multiple sites surveillance: a systemic review of the literature
}

\author{
This article was published in the following Dove Press journal: \\ Infection and Drug Resistance \\ 12 February 2016 \\ Number of times this article has been viewed
}

\section{John Chipolombwe' \\ Mili Estee Török ${ }^{2}$ \\ Nontombi Mbelle ${ }^{3}$ \\ Peter Nyasulu ${ }^{4,5}$}

'Department of Internal Medicine, Mzuzu Central Hospital, Ministry of Health, Mzuzu, Malawi; ${ }^{2}$ Department of Medicine, University of Cambridge, Cambridge, UK; ${ }^{3}$ Department of Medical Microbiology, University of Pretoria, Pretoria, South Africa; ${ }^{4} \mathrm{~S}$ chool of Public Health, Faculty of Health Sciences, University of the Witwatersrand, ${ }^{5}$ Department of Public Health, School of Health Sciences, Monash University, Johannesburg, South Africa
Correspondence: Peter Nyasulu Department of Public Health, School of Health Sciences, Monash University, I44 Peter Road, Rumsuig, Johannesburg, South Africa Tel +27 785I85225

Email peter.nyasulu@monash.edu
Purpose: The objective of this study was to evaluate the optimal number of sampling sites for detection of methicillin-resistant Staphylococcus aureus (MRSA) colonization.

Methods: We performed a Medline search from January 1966 to February 2014 for articles that reported the prevalence of MRSA at different body sites. Studies were characterized by study design, country and period of the study, number of patients and/or isolates of MRSA, specimen type, sites of MRSA isolation, study population sampled, diagnostic testing method, and percentage of the MRSA isolates at each site in relation to the total number of sites.

Results: We reviewed 3,211 abstracts and 177 manuscripts, of which 17 met the criteria for analysis ( $n=52,642$ patients). MRSA colonization prevalence varied from $8 \%$ to $99 \%$ at different body sites. The nasal cavity as a single site had MRSA detection sensitivity of $68 \%(34 \%-91 \%)$. The throat and nares gave the highest detection rates as single sites. A combination of two swabs improved MRSA detection rates with the best combination being groin/throat $(89.6 \%$; $62.5 \%-100 \%$ ). A combination of three swab sites improved MRSA detection rate to $94.2 \%$ (81\%-100\%) with the best combination being groin/nose/throat. Certain combinations were associated with low detection rates. MRSA detection rates also varied with different culture methods.

Conclusion: A combination of three swabs from different body sites resulted in the highest detection rate for MRSA colonization. The use of three swab sites would likely improve the recognition and treatment of MRSA colonization, which may in turn reduce infection and transmission of MRSA to other patients.

Keywords: Staphylococcus colonization, swab sites, MRSA detection

\section{Introduction}

Methicillin-resistant Staphylococcus aureus (MRSA) has become a major cause of hospital-associated infection since it was first discovered in Britain in the 1960s soon after the beta-lactam methicillin was introduced for clinical use against Staphylococci. ${ }^{1}$ The emergence of MRSA infection has had a negative impact on hospital costs, resulting in longer hospital stays as well as morbidity and mortality. ${ }^{2,3}$

MRSA colonization is a major risk factor for subsequent MRSA infection. ${ }^{4,5}$ In the USA and Singapore, studies found that $8.5 \%$ and $15 \%$ of MRSA-colonized patients, respectively, developed MRSA infection over subsequent years. ${ }^{4,5}$ The presence of MRSA at multiple sites strongly predicts development of MRSA infection. ${ }^{6,7}$ Colonized patients are an important reservoir of MRSA in hospitals, and diagnostic clinical samples can miss $\sim 35 \%-84 \%$ of these colonized patients. ${ }^{8,9}$ 
There is no general consensus on effective control measures and the optimum anatomical swabbing sites, which are least costly, for use as an infection control measure for MRSA. ${ }^{9}$ Studies have been devised to determine the optimal site or combination of sites for detection of MRSA colonization. Issues of detection method, cost, efficiency, accuracy, and study design have been considered. Different countries have different policies on the number of sites for screening of MRSA colonization for optimum results. In the USA, nasal swabbing as the single site is recommended while in the UK, at least two sites are recommended. ${ }^{9-11}$

Bacteremia surveillance has been used as a passive method for measuring effectiveness of MRSA control methods, but this has a disadvantage of requiring long follow-up to determine whether infection control interventions have had an effect in a hospital. ${ }^{12}$ There is a need to evaluate other surveillance measures to achieve optimum control of MRSA. ${ }^{13}$ Our study is aimed at establishing the significance of MRSA isolation from different sites suspected of colonization as a surveillance measure.

\section{Methods}

\section{Selection of articles for inclusion}

Candidate articles were selected for the reference document, first on the basis of title, and then on reading the abstract. All candidate articles were retrieved before final selection. The articles qualified for selection for review if they met the following criteria: 1) original research written in English and published in a peer-reviewed journal; 2) explicit information on MRSA colonization sites; and 3) any article published after 1966 providing data on culture isolates of MRSA at both nasal and extra-nasal and results were available.

\section{Focus of the study}

The focus of this study was, primarily, to analyze MRSA colonization sites or multiple MRSA colonization sites as a method of MRSA detection.

\section{Literature search}

The study was based on an updated literature search in Medline. The search terms were: "MRSA surveillance", "Methicillin-resistant Staphylococcus aureus surveillance", "MRSA", "colonization site", ("Screening" OR Swab OR surveillance AND MRSA). The database search was supplemented by a bibliographic search in previous reviews in the field. The authors read all the abstracts to retrieve relevant articles, minimizing the possibility of selective selection.

\section{Data extraction}

The data extracted from each of the included studies consisted of the first author; year of publication; study design; country and period of the study; number of patients and/ or isolates of MRSA; and the type of the culture specimen for MRSA, the site of MRSA isolation, and the percentage sensitivity of the MRSA isolates at each site in relation to the total sites.

\section{Results}

We reviewed 3,211 abstracts and 177 manuscripts, and 160 were excluded either due to the fact that the swabbing data were only from nasal sites or that the study population were mostly children. Seventeen full articles met the criteria for analysis as they had data on screening of both nasal and extra-nasal sites of adults at admission (Table 1). ${ }^{140}$ The studies included for analysis were conducted between 1996 and 2014 ( $n=52,642$ patients). Seven of the studies were conducted in South America, six in Europe, four in Asia, and none in Africa. Seven studies had study population from general wards, six from intensive care unit (ICU), and three from both ICU and general wards, while one was conducted on ward and outpatients. Eleven studies were prospectively while six were retrospectively done. Out of the 17 studies, 16 of them used directly plated MRSA culture media and one used both directly plated MRSA culture media and brothenriched culture media. MRSA isolates were confirmed by disc diffusion assay in 16 studies, and in one study MRSA isolates were confirmed by both disc diffusion and molecular assays. Four studies had low MRSA prevalence of less than $6 \%(1.3 \%-4.1 \%)$, while the prevalence of MRSA in nine studies were high at $\geq 6 \%(6 \%-25 \%)$, and four studies did not state the prevalence of MRSA.

Fifteen of the 17 studies had nasal MRSA detection of less than $90 \%$ as a single area of MRSA colonization and the MRSA detection ranged from $34 \%$ to $89.7 \%$, and only two of the 15 studies had MRSA nasal sensitivity of $\geq 90 \%$ as a single area of MRSA colonization. ${ }^{24,25}$ The single-site screening of nares showed low MRSA in endemic areas ${ }^{15,19,25,27}$ due to a high proportion of MRSA detected by nasal screening of $75.1 \%$ with a range of $(65 \%-90 \%)$ (Table 2$)$. Nasal colonization showed MRSA detection sensitivity of less than $50 \%$ $(34 \%-48 \%)$ in three studies. ${ }^{16,21,29}$

Seven studies showed less than $90 \%$ MRSA detection sensitivity when nasal MRSA colonization was combined with one extra-nasal site. ${ }^{14,16,19,20,23,29,30}$ Four studies had nasal/ throat; five studies nasal or throat/groin; three studies had nasal/rectum; and one study had nasal/skin or wound as 
best two combinations for MRSA detection sensitivity. Four studies had nasal/throat/groin; three studies had nasal/throat/ rectum; while each of the two single studies had nasal/axilla/ rectum and nasal/wound/perineum, respectively, as three best combinations for MRSA detection sensitivity (Table 1). Detection of MRSA colonization was enhanced by using broth-enriched culture media and performing molecular assay, and this helped in rapid detection and identification of MRSA from mixed flora samples. ${ }^{20,22}$

\section{Discussion}

Colonized patients are important reservoir of MRSA in hospitals, and diagnostic clinical samples can miss $\sim 35 \%-84 \%$ of these colonized patients. ${ }^{8,9}$ The level of endemicity of MRSA determines the kind of screening program needed in order not to miss occult carriers of MRSA and, therefore, increase cross transmission of MRSA hospital infection. ${ }^{19,25,26}$ The importance of doing the MRSA colonization screening has been marred with issues of cost-benefit analysis and the indication for it. ${ }^{19,22,27}$ Various countries have different policies on the number of sites for screening of MRSA colonization with optimum results.

Prevalence of MRSA colonization is not the same on different sites of patients' body, such as the axilla, hairline, groin, nose, perineum, rectum, throat, skin breakdown areas, eyes, and vagina. ${ }^{14-30}$ The throat and nares show higher colonization detection as single sites ranging from $50.5 \%$ to $89.7 \%$. $^{14-20,22-28,30}$ The two studies that showed $\geq 90 \%$ nasal MRSA colonization sensitivity as single site still needed extra-nasal combination to have required Negative Predictive Value of MRSA detection. ${ }^{24,25}$ Single-site screening such as the nasal cavity is optimal for endemic areas with low MRSA prevalence, ${ }^{15,19,25,27}$ and this single site is likely to miss significant detection of MRSA colonization in high-risk population. ${ }^{14-16,21,29}$ The nasal cavity as a single site for detection of MRSA colonization was not able to meet MRSA detection of $\geq 90 \%$ in 15 of the 17 studies under review. ${ }^{14-23,26-30}$ The study by El-Bouri ${ }^{14}$ found $50 \%$ of two swab combinations were better than single nasal swabbing and $25 \%$ were likely missed by using nasal swabbing alone. This was also found in studies by Mertz et al and Bignardi and Lowes. ${ }^{31-34}$

Combination swabs from two sites improved MRSA detection rate to $50 \%$ with best combination being that of nasal or throat/groin, ${ }^{18,22,24,28}$ followed by nasal/rectum or perineum. ${ }^{15,17,21}$

A three-site combination improved detection rate to $99 \%$ with the best combination being that of nasal/throat/ groin or perineum or rectum. ${ }^{14,16,19,20,28,30}$ In another study, the three-site combination did not reach the $\geq 90 \%$ sensitivity, ${ }^{23}$ though the overall MRSA colonization at any site was $12.2 \%$ $(1.3 \%-24 \%)$, and this could be due to a variation in the MRSA detection method. Nasal colonization was $47.6 \%$ $(22.2 \%-87 \%)$, nasal plus one extra-nasal combination was $89.6 \%(62.5 \%-100 \%)$, and nasal plus two extra-nasal sites combination was 94.2\% (81\%-100\%), as shown in Table 2. Similar findings were reported in a systematic review conducted by McKinnell et al. ${ }^{31}$

Most of the studies under review for extra-nasal screening were done in developed countries of USA, Europe, and Asia even though many studies have indicated the prevalence of MRSA in countries of Africa. Apart from level of endemicity, cost-benefit analysis has been mainly put under consideration when it comes to either using nasal swabbing alone or combination of extra-nasal sites. ${ }^{15,32,35}$ Another issue is to do with acceptability of the method of swabbing at certain sites, like throat and perineum, by the study population. ${ }^{15,27,36-39}$ Some studies found that throat swabbing was better at MRSA detection than nasal swabbing. ${ }^{14,16,27,36-39}$ Fifteen of the 17 studies (88\%) reviewed favored inclusion of extra-nasal swabbing for the detection of MRSA colonization. Two studies under review showed that the method of MRSA detection has effect on the detection of MRSA at different sites. ${ }^{20,22}$ Lauderdale et $\mathrm{al}^{20}$ found that direct culture method missed $\sim 50 \%$ detection rate of MRSA from nasal swabbing as compared to broth-enriched medium. Broth-enriched culture improved detection rate of MRSA by $24 \%$ in swabs from the throat, axilla, and perineum. These results concurred with those of GrmekKosnik et al and Nonhoff et al. ${ }^{40,41}$ The variation in the detection rate at different sites could also be attributed to MRSA load and method of detection and decolonization procedures. ${ }^{23,42}$ The association was not seen in the study by Baker et al, ${ }^{23}$ where it was found that the strongest predictor of extra-nasal colonization was nasal colonization and not broth-enriched medium. Currie et $\mathrm{al}^{15}$ found that the sensitivity of rectal swabs increased from $59 \%$ to $67 \%$ for MRSA-Select plates when mannitol-salt agar (MSA-OX) with $4 \mathrm{mg} / \mathrm{L}$ oxacillin culture was used, but there was no significant change in sensitivities of nasal and open-skinsite swabs with MSA-OX culture. Use of PCR methods did not show any significant difference in the detection of MRSA. ${ }^{23}$ The anatomical sites to be swabbed also have an effect on the culture results due to the fact that participants may decline to give consent, due to psycho-social stigma associated with very private or anatomically sensitive areas of the body to be swabbed. The throat or posterior pharynx, 
Table I Participants, bacteriological testing, and outcomes of MRSA testing for identification of sites of MRSA colonization

\begin{tabular}{|c|c|c|c|c|c|}
\hline $\begin{array}{l}\text { Author name, } \\
\text { country }\end{array}$ & Period of study & $\begin{array}{l}\text { Study } \\
\text { design }\end{array}$ & MRSA detection method & $\begin{array}{l}\text { Swabbing method } \\
\text { and site }\end{array}$ & $\begin{array}{l}\text { Study population } \\
\text { and size }\end{array}$ \\
\hline $\begin{array}{l}\text { El-Bouri and } \\
\text { El-Bouri, }{ }^{14} \text { Wales }\end{array}$ & $\begin{array}{l}\text { January } 2010- \\
\text { November } 2012\end{array}$ & Retrospective & $\begin{array}{l}\text { Chromogenic MRSA medium/ } \\
\text { Columbia blood agar }\end{array}$ & $\begin{array}{l}\text { Only simultaneously swabbed } \\
\text { patients of all anatomical sites } \\
\text { were accepted }\end{array}$ & $\begin{array}{l}\text { Adults at high risk for } \\
\text { MRSA due to frequent } \\
\text { re-admission or } \\
\text { others }(4,769)\end{array}$ \\
\hline $\begin{array}{l}\text { Currie et al, }{ }^{15} \\
\text { Canada }\end{array}$ & $\begin{array}{l}\text { January 2004- } \\
\text { June } 2007\end{array}$ & $\begin{array}{l}\text { Descriptive } \\
\text { analysis }\end{array}$ & $\begin{array}{l}\text { MSA-OX, } \\
\text { MSA-FOX, } \\
\text { MRSA-Select }\end{array}$ & First set of screening swabs & $\begin{array}{l}\text { All surgical and medical } \\
\text { patient with HA-MRSA } \\
\text { risk factors }(23,365)\end{array}$ \\
\hline $\begin{array}{l}\text { Jang et al, }{ }^{16} \\
\text { Republic of Korea }\end{array}$ & $\begin{array}{l}\text { March 20I0- } \\
\text { February 20II }\end{array}$ & $\begin{array}{l}\text { Prospective } \\
\text { observational }\end{array}$ & $\begin{array}{l}\mathrm{BBL}^{\mathrm{TM}} \text { CHROMagar }{ }^{\mathrm{TM}} \text { MRSA } \\
\text { medium }\end{array}$ & $\begin{array}{l}\text { Swabbed at the time of } \\
\text { admission, } 48 \text { hours after } \\
\text { admission, and then weekly }\end{array}$ & Adult patients (282) \\
\hline Yang et al, ${ }^{17}$ USA & $\begin{array}{l}\text { February 2005- } \\
\text { October } 2007\end{array}$ & Prospectively & MSA-OX & $\begin{array}{l}\text { Swabbing once at anatomic } \\
\text { sites in MRSA infected patients }\end{array}$ & Adults with SSTIs (II7) \\
\hline Datta et al, ${ }^{18}$ India & $\begin{array}{l}\text { January 2009- } \\
\text { June } 2010\end{array}$ & $\begin{array}{l}\text { Active } \\
\text { surveillance }\end{array}$ & $\begin{array}{l}\text { Blood agar and Mac Conkey } \\
\text { agar and disc diffusion test } \\
\text { using } 30 \text { ug cefoxitin disc on } \\
\text { Mueller Hinton agar }\end{array}$ & Single anatomic swabbing & Adults in ICU (400) \\
\hline $\begin{array}{l}\text { Girou et al, }{ }^{19} \\
\text { France }\end{array}$ & $1993-1996$ & Prospective & Chapman agar & $\begin{array}{l}\text { Swab from nasal, perineum, } \\
\text { and axilla at admission and } \\
\text { once a week }\end{array}$ & $\begin{array}{l}\text { High-risk patients } \\
\text { from MICU }(3,686)\end{array}$ \\
\hline $\begin{array}{l}\text { Lauderdale et al, }{ }^{20} \\
\text { Taiwan }\end{array}$ & $\begin{array}{l}\text { August 2005- } \\
\text { February } 2006\end{array}$ & Retrospective & $\begin{array}{l}\text { Sheep blood agar (SBA) and } \\
\text { CHROM agar MRSA and } \\
\text { broth-enriched culture }\end{array}$ & $\begin{array}{l}\text { Swab sample set of nose, } \\
\text { throat or sputum, axilla, } \\
\text { and perineum within } \\
24 \text { hours admission }\end{array}$ & $\begin{array}{l}\text { Patients on admission } \\
\text { to a medical and } \\
\text { surgical ICU }(650)\end{array}$ \\
\hline $\begin{array}{l}\text { Eveillard et al, }{ }^{21} \\
\text { France }\end{array}$ & $\begin{array}{l}\text { July } 2002- \\
\text { June } 2003\end{array}$ & Prospective & $\begin{array}{l}\text { Mannitol salt agar } \\
\text { (MSA-Ofloxacin) }\end{array}$ & $\begin{array}{l}\text { Screen swab at different } \\
\text { anatomic sites on } \\
\text { admission and also clinical } \\
\text { sample and TID calculated }\end{array}$ & $\begin{array}{l}\mathrm{I}, 250 \text { from ICU and } \\
\text { other wards }\end{array}$ \\
\hline $\begin{array}{l}\text { Hombach et al, }{ }^{22} \\
\text { Switzerland }\end{array}$ & $\begin{array}{l}\text { August 2007- } \\
\text { August } 2008\end{array}$ & Prospective & $\begin{array}{l}\text { BD GeneOhm }{ }^{\mathrm{TM}} \text { MRSA Assay, } \\
\text { the } \text { Xpert }^{\mathrm{TM}} \text { MRSA assay } \\
\text { and broth-enriched culture }\end{array}$ & $\begin{array}{l}\text { Swabs from different sites on } \\
\text { admission from MRSA } \\
\text { high-risk patients }\end{array}$ & 425 \\
\hline Baker et al, ${ }^{23}$ USA & $\begin{array}{l}\text { October 2008- } \\
\text { February } 2009\end{array}$ & Prospective & Chromogenic agar plate & $\begin{array}{l}\text { Swabs from acute care patients } \\
\text { within } 36 \text { hours of admission }\end{array}$ & 150 \\
\hline Mermel et al, ${ }^{24}$ USA & $\begin{array}{l}\text { September 2007- } \\
\text { March } 2008\end{array}$ & Retrospective & $\begin{array}{l}\text { MRSA-selective chromogenic } \\
\text { medium and sheep blood agar }\end{array}$ & $\begin{array}{l}\text { Adults inpatients previously } \\
\text { identified as MRSA positive } \\
\text { during the year prior to } \\
\text { enrollment }\end{array}$ & 53 \\
\hline Fishbain et $a l,{ }^{25}$ USA & $\begin{array}{l}\text { August- } \\
\text { November } 2000\end{array}$ & $\begin{array}{l}\text { Prospective } \\
\text { surveillance }\end{array}$ & $\begin{array}{l}5 \% \text { sheep agar and MRSA } \\
\text { screen agar }\end{array}$ & $\begin{array}{l}\text { Adults on admission, swabs } \\
\text { within } 48 \text { hours from both } \\
\text { nares and both axilla }\end{array}$ & 535 \\
\hline Lucet et al, ${ }^{26}$ France & $\begin{array}{l}\text { July 1997- } \\
\text { December } 1997\end{array}$ & $\begin{array}{l}\text { Prospective } \\
\text { multicenter }\end{array}$ & $\begin{array}{l}\text { Various media according } \\
\text { to center }\end{array}$ & $\begin{array}{l}\text { Adults in ICU swabs within } \\
24 \text { hours admission from nose } \\
\text { and skin (both axilla and groin) }\end{array}$ & 2,347 \\
\hline $\begin{array}{l}\text { Papia et al, }{ }^{27} \\
\text { Canada }\end{array}$ & $\begin{array}{l}\text { May } 1996- \\
\text { May } 1997\end{array}$ & Case control & Mannitol agar & $\begin{array}{l}\text { Swabs from adults in acute } \\
\text { care ward from different sites }\end{array}$ & $\mathrm{I}, 742$ \\
\hline $\begin{array}{l}\text { Lautenbach et al, }{ }^{28} \\
\text { USA }\end{array}$ & $\begin{array}{l}\text { January 2008- } \\
\text { May } 2008\end{array}$ & Cross-section & ChromAgar & $\begin{array}{l}\text { Swabs on admission by } \\
\text { research nurse and self on } \\
\text { admission from different sites }\end{array}$ & 56 \\
\hline Senn et al, ${ }^{29}$ USA & 2006-2009 & Retrospective & $\begin{array}{l}\text { M-Staphylococcus and } \\
\text { MRSA-select agar }\end{array}$ & $\begin{array}{l}\text { Swabs from different anatomic } \\
\text { sites on admission for culture } \\
\text { and PCR on adults }\end{array}$ & 12,456 \\
\hline $\begin{array}{l}\text { Bitterman et al, }{ }^{30} \\
\text { Israel }\end{array}$ & 2003-2006 & Retrospective & BBL CHROMagar MRSA & $\begin{array}{l}\text { Swabs from sites from } \\
I C U \text { and non-ICU patients } \\
\text { from screening sample (SS) and } \\
\text { clinical diagnostic sample (CDS) }\end{array}$ & Not stated \\
\hline
\end{tabular}




\begin{tabular}{|c|c|c|c|c|c|}
\hline \multirow{2}{*}{$\begin{array}{l}\text { MRSA positive } \\
\text { number }(\%)\end{array}$} & \multicolumn{3}{|c|}{ MRSA site colonization } & \multicolumn{2}{|l|}{ Best site combination } \\
\hline & Nasal & Extra-nasal & $\begin{array}{l}\text { Proportion to be } \\
\text { missed if nasal alone }\end{array}$ & Two & Three \\
\hline $925 / 4,769$ (19.4\%) & $467 / 925$ (50.5\%) & $458 / 925$ (49.5\%) & $365(39.5 \%)$ & $\begin{array}{l}\text { Throat/groin } 74.5 \% \\
(71.7-77.3) \\
\text { Nose/groin } 72.1 \% \\
(69.2-75)\end{array}$ & $\begin{array}{l}\text { Throat/nose/groin } \\
92 \%(90.1-93.6) \\
\text { Nose/throat/perineum } \\
91 \%(88.9-92.7)\end{array}$ \\
\hline $627 / 2,3365$ (2.7\%) & $419 / 627(66.8 \%)$ & $208 / 627$ (33.1\%) & $160(34 \%)$ & $\begin{array}{l}\text { Nares/rectum } 586 / 612 \\
(96 \% 94-98)\end{array}$ & \\
\hline \multirow[t]{2}{*}{$59 / 282(21 \%)$} & $20 / 59(34 \%)$ & $39 / 59(66.1 \%)$ & $66 \%$ & $\begin{array}{l}\text { Nasal/throat 50/59 } \\
(84.7 \%)\end{array}$ & $\begin{array}{l}\text { Nasal/throat/rectum } \\
(94.9 \%)\end{array}$ \\
\hline & $48 / 7$ I (67\%) & 23/7I (32.4\%) & $|7 / 7|(24 \%)$ & Nasal/inguinal (96\%) & \\
\hline $90 / 400$ (22.5\%) & $70 / 90(77.8 \%)$ & $20 / 90(22.2 \%)$ & $\mathrm{II}(12.2 \%)$ & $\begin{array}{l}\text { Nose/throat } 86 / 90(95.5 \%) \text {, } \\
\text { Throat/groin } 84 / 90 \text { (93.3\%), } \\
\text { Nose/groin } 82 / 90 \text { (9l.1\%) }\end{array}$ & \\
\hline I50/3,686 (4.1\%) & $35 / 45$ (78.5\%) & $16 / 45(35.6 \%)$ & $5 / 45$ (II\%) & Nasal/perineum (88.9\%) & $\begin{array}{l}\text { Nasal/throat/perineum } \\
(98 \%)\end{array}$ \\
\hline $\begin{array}{l}65 / 650 \text { (10\%) Direct } \\
\text { culture ( } 157 / 650 \\
{[24 \%] \text { broth- }} \\
\text { enriched) }\end{array}$ & II4/I57 (72.6\%) & $43 / 157(27.3 \%)$ & $27(17.2 \%)$ & Nasal/throat I34/I57 (85.4\%) & $\begin{array}{l}\text { Nasal/throat/perineum } \\
\text { 146/I57 (93.2\%) }\end{array}$ \\
\hline I23/I,250 (9.8\%) & $53 / 123(43.1 \%)$ & $70 / 123(56.9 \%)$ & $54.3 \%$ & Nose/rectum (91.9\%) & $\begin{array}{l}\text { Nose/axilla/rectum } \\
(100 \%)\end{array}$ \\
\hline $29 / 425$ (6.8\%) & $26 / 29(89.7 \%)$ & $22 / 29(76 \%)$ & $\leq 1$ & Nose/groin (100\%) & \\
\hline $16 / 150(10.7 \%)$ & $9 / 16(56.2 \%)$ & 6/16 (37.5\%) & $3(2 \%)$ & Nasal/oropharynx (62.5\%) & $\begin{array}{l}\text { Nasal/oropharynx/ } \\
\text { perineum }(81 \%)\end{array}$ \\
\hline Not stated & $48 / 53(91 \%)$ & $40 / 53(75.5 \%)$ & $\begin{array}{l}\text { Similar sensitivity but } \\
\text { combined samples } \\
\text { increasing negative } \\
\text { predictive value }\end{array}$ & Nares/groin (98\%) & \\
\hline $20 / 535(3.7 \%)$ & $18 / 20(90 \%)$ & $5 / 20(25 \%)$ & $\begin{array}{l}\text { Similar sensitivity but } \\
\text { combined samples } \\
\text { increasing negative } \\
\text { predictive value }\end{array}$ & Nasal/axillary (100\%) & \\
\hline 162/2,347 (6.9\%) & I26/162 (77.8\%) & $72 / 162(44.4 \%)$ & $19 / 162(7.2 \%)$ & Nasal/skin I48/I62 (92\%) & \\
\hline $23 / 1,742$ (1.3\%) & $15 / 23(65.2 \%)$ & $13 / 23(56.5 \%)$ & $6 / 23(26.1 \%)$ & Nasal/wound (91.3\%) & $\begin{array}{l}\text { Nasal/wound/ } \\
\text { perineum (95.7\%) }\end{array}$ \\
\hline Not stated & $46 / 55(84 \%)$ & $48 / 55$ (87\%) & $3 / 55(5.5 \%)$ & Nares/throat 50/55 (91\%) & $\begin{array}{l}\text { Nares/throat/groin } \\
(98 \%)\end{array}$ \\
\hline $3,137 / 12,456$ (25.2\%) & I,509/3, I37 (48\%) & I,628/3, 137 (51.9\%) & $\mathrm{I}, 320 / 3,137$ (42.1\%) & Groin/throat (89\%) & $\begin{array}{l}\text { Nose/groin/throat } \\
(96 \%)\end{array}$ \\
\hline 359 & $243 / 359(67.7 \%)$ & $117 / 359$ (32.3\%) & $80 / 359$ (22.2\%) & Nares/perineum (89.6\%) & $\begin{array}{l}\text { Nares/perineum/ } \\
\text { throat }(93.6 \%)\end{array}$ \\
\hline
\end{tabular}

Abbreviations: OX, Ofloxacin; FOX, cefoxitin; MRSA, methicillin-resistant Staphylococcus aureus; TID, theoretical isolation days; ICU, intensive care unit; HA, hospital associated; SSTI, skin and soft tissue infection; MICU, medical ICU; PCR, polymerase chain reaction. 


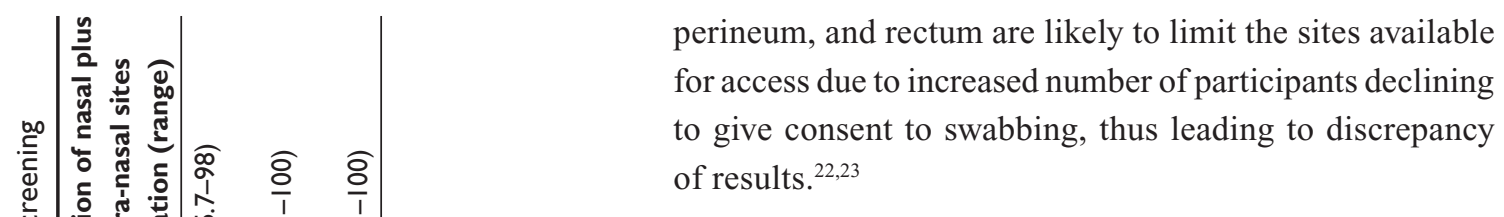

\section{Conclusion}

We concur with previous published findings based on localized research analysis. Our systemic review of 52,642 cases indicates that a combination of three swabs from different sites provided the highest detection rate of MRSA colonization. The use of three swab sites is likely to improve recognition and treatment of MRSA, which may in turn reduce infection and transmission to other patients in hospital despite associated incremental costs.

\section{Recommendation}

The prevalence of MRSA carriage plays an important role in strategies used to manage colonization. The decision on the optimal sampling sites for MRSA detection should be determined by the goal of the intervention. If the intention is eradication in low-prevalence, MRSA-colonized populations, prospective surveillance and infection control should be reenforced. For reduction in high-prevalence settings, prospective surveillance should be considered with universal screening.

\section{Disclosure}

The authors report no conflicts of interest in this work.

\section{References}

1. Jevons MP. Celbenin resistant staphylococci. Br Med J. 1961;1: $124-125$.

2. Cosgrove SE, Qi Y, Kaye KS, Harbarth S, Karchmer AW, Carmeli Y. The impact of methicillin resistance in Staphylococcus aureus bacteremia on patient outcomes: mortality, length of stay, and hospital charges. Infect Control Hosp Epidemiol. 2005;26:166-174.

3. Pada SK, Ding Y, Ling ML, et al. Economic and clinical impact of nosocomial methicillin-resistant Staphylococcus aureus infections in Singapore: a matched case-control study. $J$ Hosp Infect. 2011;78:36-40.

4. Ramarathnam V, De Marco B, Ortegon A, Kemp D, Luby J, Sreeramoju P. Risk factors for development of methicillin-resistant Staphylococcus aureus infection among colonized patients. Am J Infect Control. 2013; 41(7):625-628.

5. Balm MND, Lover AA, Salmon S, Tamyah P, Fisher DA. Progression from new Methicillin-resistant Staphylococcus aureus colonization to infection: an observation study in a hospital cohort. BMC Infect Dis. 2013;13:491.

6. Kluytmans JA, Wertheim HF. Nasal carriage of Staphylococcus aureus and prevention of nosocomial infections. Infection. 2005;33:3-8.

7. Davis KA, Stewart JJ, Crouch HK, Florez CE, Hospenthal DR. Methicillin-resistant Staphylococcus aureus (MRSA) nares colonization at hospital admission and its effect on subsequent MRSA infection. Clin Infect Dise. 2004;39:776-782.

8. Grundmann H, Aires-de-Sousa M, Boyce J, Tiemersma E. Emergence and resurgence of meticillin-resistant Staphylococcus aureus as a publichealth threat. Lancet. 2006;368(9538):874-885. 
9. Struelens MJ, Hawkey PM, French GL, Witte W, Tacconelli E. Laboratory tools and strategies for methicillin-resistant Staphylococcus aureus screening, surveillance and typing: state of the art and unmet needs. Clin Microbiol Infect. 2009;15(2):112-119.

10. Health Protection Scotland. NHS Scotland MRSA Screening Pathfinder Programme. An Investigation of the Clinical Effectiveness of Universal MRSA Screening: Final Report Volume 1. Available from: $h t t p: / / w w w$. documents.hps.scot.nhs.uk/hai/mrsa-screening/pathfinder-programme/ mrsa-pathfinder-vol12011-02-23. Accessed October 14, 2015.

11. Arnold MS, Dempsey JM, Fishman M, McAuley PJ, Tibert C, Vallande NC. Methicillin Resistant Staphylococcus aureus (MRSA) best practices guidelines for hospitals. Available from: www.health.ri.gov/ publications/guidelines/MRSAHospital.pdf. Accessed October 14, 2015.

12. Loveday HP, Pellowe CM, Jones SR, Pratt RJ. A systematic review of the evidence for interventions for the prevention and control of meticillin-resistant Staphylococcus aureus (1996-2004): report to the Joint MRSA Working Party (Subgroup A). J Hosp Infect. 2006; 63(Suppl 1):S45-S70.

13. Wyllie D, Walker S, Peto TEA, O'Connor L, Derrick W. Crook DW. Are there better methods of monitoring MRSA control than bacteraemia surveillance? An observational database study. PLoS One. 2008;3(6): e2378.

14. El-Bouri K, El-Bouri W. Screening cultures for detection of methicillinresistant Staphylococcus aureus in a population at high risk for MRSA colonization: identification of optimal combinations of anatomical sites. LJM. 2013;8:22755.

15. Currie A, Davis L, Odrobina E, et al. Sensitivities of nasal and rectal swabs for detection of methicillin-resistant Staphylococcus aureus colonization in an active surveillance program. J Clin Microbiol. 2008; 3101-3103.

16. Jang H, Choi O, Kim G, et al. Active surveillance of the trachea or throat MRSA is more sensitive than nasal surveillance and a better predictor of MRSA infections among patients in intensive care. PLoS One. 2014;9(6):e99192.

17. Yang ES, Tan J, Eells S, Rieg G, Tagudar G, Miller LG. Body site colonization in patients with community-associated methicillin-resistant Staphylococcus aureus and other types of S. aureus skin infections. Clin Microbiol Infect. 2010;16:425-431.

18. Datta P, Vasdeva HR, Chander J. Optimization of multiple mucocutaneous site sampling method for screening MRSA colonization in ICU. Indian J Crit Care Med. 2013;17(4):243-245.

19. Girou E, Pujade G, Cizeau PLF, Brun-Buisson C. Selective screening of carriers for control of methicillin-resistant Staphylococcus aureus (MRSA) in high-risk hospital areas with a high level of endemic MRSA. Clin Infect Dis. 1998;27:543-550.

20. Lauderdale TLY, Wang JT, Lee WS, et al. Carriage rates of methicillinresistant Staphylococcus aureus (MRSA) depend on anatomic location, the number of sites cultured, culture methods, and the distribution of clonotypes. Eur J Clin Microbiol Infect Dis. 2010;29:1553-1559.

21. Eveillard M, Lassence A, Lancien E, Barnaud G, Ricard J, Joly-Guillou M. Evaluation of a strategy of screening multiple anatomical sites for methicillin-resistant Staphylococcus aureus at admission to a teaching hospital. Infect Control Hosp Epidemiol. 2006;27:181-184.

22. Hombach M, Pfyffer GE, Roos M, Lucke K. Detection of MRSA in specimens from various body sites: performance characteristics of the BD GeneOhm ${ }^{\mathrm{TM}}$ MRSA Assay, the Xpert ${ }^{\mathrm{TM}}$ MRSA assay, and broth-enriched culture in a low-prevalence area. J Clin Microbiol. 2010;48(11):3882-3887.

23. Baker SE, Brecher SM, Robillard E, Strymish J, Lawler E, Gupta K. Extranasal methicillin-resistant Staphylococcus aureus colonization at admission to an acute care veterans affairs hospital. Infect Control Hosp Epidemiol. 2010;31:42-46.

24. Mermel LA, Cartony JM, Covington P, Maxey G, Morse D. Methicillinresistant Staphylococcus aureus colonization at different body sites: a prospective, quantitative analysis. J Clin Microbiol. 2011;49(3): 1119-1121.
25. Fishbain HT, Lee JC, Nguyen HD, et al. Nosocomial transmission of methicillin-resistant Staphylococcus aureus: a blinded study to establish baseline acquisition rates. Infect Control Hosp Epidemiol. 2003;24(6):415-421.

26. Lucet JC, Chevret S, Durand-Zaleski I, Chastang C, Regnier B. Prevalence and risk factors for carriage of methicillin-resistant Staphylococcus aureus at admission to the intensive care unit. Arch Intern Med. 2003;163:181-188.

27. Papia G, Louie M, Arnold Tralla A, Johnson C, Collins V, Simor AE. Screening high-risk patients for methicillin-resistant Staphylococcus aureus on admission to the hospital: is it cost effective? Infect Control Hosp Epidemiol. 1999;20(7):473-477.

28. Lautenbach E, Nachamkin I, Hu B, Fishman et al. Surveillance cultures for detection of methicillin-resistant Staphylococcus aureus: diagnostic yield of anatomic sites and comparison of provider- and patient-collected samples. Infect Control Hosp Epidemiol. 2009;30(4):380-382.

29. Senn L, Basset P, Nahimana I, Zanetti G, Blanc DS. Which anatomical sites should be sampled for screening of methicillin-resistant Staphylococcus aureus carriage by culture or by rapid PCR test? Clin Microbiol Infect. 2012;18:E31-E33.

30. Bitterman Y, Laor A, Itzhaki S, Weber G. Characterization of the best anatomical sites in screening for methicillin-resistant Staphylococcus aureus colonization. Eur J Clin Microbiol Infect Dis. 2010;29: 391-397.

31. McKinnell JA, Huang SS, Eells SJ, Cui E, Miller LG. Quantifying the impact of extra-nasal testing body sites for MRSA colonization at the time of hospital or intensive care unit admission. Infect Control Hosp Epidemiol. 2013;34(2):161-170.

32. Mertz D, Frei R, Jaussi B, et al. Throat swabs are necessary to reliably detect carriers of Staphylococcus aureus. Clin Infect Dis. 2007;45: 475-477.

33. Bignardi GE, Lowes S. MRSA screening: throat swabs are better than nose swabs. J Hosp Infect. 2009;71:373-374.

34. Mertz D, Frei R, Periat N, et al. Exclusive Staphylococcus aureus throat carriage: at-risk populations. Arch Intern Med. 2009;169:172-178.

35. Nilsson P, Ripa T. Staphylococcus aureus throat colonization is more frequent than colonization in the anterior nares. $J$ Clin Microbiol. 2006; 44:3334-3339

36. Rao N, Jacobs S, Joyce L. Cost-effective eradication of an outbreak of methicillin-resistant Staphylococcus aureus in a community teaching hospital. Infect Control Hosp Epidemiol. 1988;9:255-260.

37. Coia JE, Duckworth GJ, Edwards DI, et al. Guidelines for the control and prevention of meticillin-resistant Staphylococcus aureus (MRSA) in healthcare facilities. J Hosp Infect. 2006;63(Suppl 1):S1-S44.

38. Muto CA, Jernigan JA, Ostrowsky BE, et al. SHEA guideline for preventing nosocomial transmission of multidrug-resistant strains of Staphylococcus aureus and Enterococcus. Infect Control Hosp Epidemiol. 2003;24:362-386.

39. Provincial Infectious Diseases Advisory Committee. Best practices for infection prevention and control of resistant Staphylococcus aureus and enterococci. Toronto, ON, Canada: Ministry of Health and Long-Term Care. 2007;1-88.

40. Grmek-Kosnik I, Ihan A, Dermota U, Rems M, Kosnik M, Jorn Kolmos H. Evaluation of separate vs pooled swab cultures, different media, broth enrichment and anatomical sites of screening for the detection of methicillin-resistant Staphylococcus aureus from clinical specimens. $J$ Hosp Infect. 2005;61:155-161.

41. Nonhoff C, Denis O, Brenner A, et al. Comparison of three chromogenic media and enrichment broth media for the detection of methicillin-resistant Staphylococcus aureus from mucocutaneous screening specimens. Eur J Clin Microbiol Infect Dis. 2009;28:363-369.

42. Senn L, Van Heirstraeten L, Cortiñas Abrahantes J, et al; on behalf of the MOSAR WP2 Study Group. Impact of a short period of preenrichment on detection and bacterial loads of methicillin-resistant Staphylococcus aureus from screening specimens. J Clin Microbiol. 2009; 47:3326-3328. 
Infection and Drug Resistance

Dovepress

\section{Publish your work in this journal}

Infection and Drug Resistance is an international, peer-reviewed openaccess journal that focuses on the optimal treatment of infection (bacterial, fungal and viral) and the development and institution of preventive strategies to minimize the development and spread of resistance. The journal is specifically concerned with the epidemiology of antibiotic

resistance and the mechanisms of resistance development and diffusion in both hospitals and the community. The manuscript management system is completely online and includes a very quick and fair peerreview system, which is all easy to use. Visit http://www.dovepress.com/ testimonials.php to read real quotes from published authors.

Submit your manuscript here: http://www.dovepress.com/infection-and-drug-resistance-journal 